\title{
Pemanfaatan Siter, Kendang, Saron, Kenong, dan Gender sebagai media pembelajaran fisika
}

\author{
Eko Nursulistiyo \\ Program Studi Pendidikan Fisika, FKIP, Universitas Ahmad Dahlan \\ Jl. Ringroad Selatan, Tamanan, Banguntapan, Bantul, Daerah Istimewa Yogyakarta \\ Surat-e: ekonur.uad@gmail.com
}

Telah dilakukan kajian mengenai pemanfaatan siter, kendang, kenong, saron, dan gender dalam gamelan sebgai media pembelajaran fisika. Tujuan dari kajian ini adalah untuk mengetahui konsep apa saja yang bisa diajarkan menggunakan media pembelajaran gamelan dan bagaimana caranya. Metode yang digunakan adalah dengan studi pustaka dan pandalaman. Hasilnya adalah a) Siter dapat digunakan untuk menjelaskan konsep getaran, tinggi rendah bunyi dan hubungan panjang tali dengan frekuensi bunyi. Frekuensi bunyi diukur menggunakan aplikasi sound analyser free, b) Kendang dapat digunakan untuk menjelaskan konsep bunyi berasal dari getaran melalui eksperimen dengan menaburkan beras diatasnya, c) Saron dan kenong dapt digunakan untuk menjelaskan tinggi-rendah dan kuat lemah bunyi dengan memukul pada nada berbeda untuk mengajarkan tinggi rendah bunyi dan mengatur tinggi rendahnya pemukul untuk mengajarkan kuat lemah bunyi, d) Gender dapat digunakan untuk menjelaskan resonansi bunyi pada pipa organa tertutup dengan mengukur kedalaman dari kolom di bawah bilah logam dan mencatat frekuensinya.

Studies have been carried out regarding the use of siter, kendang, kenong, saron, and gender in gamelan as a medium for learning physics. The purpose of this study is to find out what concepts can be taught using gamelan learning media and how. The method used is by literature study. The result is a). "Siter" can be used to explain the concept of vibration, high low sound and the relationship of the length of the rope to the sound frequency. Sound frequency is measured using the sound analyzer free application, b). "Kendang" can be used to explain the concept of sound originating from vibrations through experiments with sprinkling rice on it, c). "Saron" and "kenong" can be used to explain the high and low weak sound by hitting on a different tone to teach high low sound and set the height of the paddle to teach strong weak sound, d). "Gender" can be used to explain sound resonance in a closed organ pipe by measuring the depth of the column under the metal blade and recording its frequency.

Kata kunci: gamelan, pembelajaran fisika, getaran, bunyi

\section{Pendahuluan}

Gamelan adalah identitas bangsa Indonesia. Gamelan yang mrupakan salah satu komponen dari pertunjukan wayang kulit merupakan salah satu ciri khas bangsa Indonesia dibandingkan dengan negara lain. Identitas sebuah bangsa akan hilang apabila kita tidak mencintai gamelan sebagai salah satu ciri khas bangsa Indonesia.

Konsep kebudayaan dapat didefinisikan sebagai keseluruhan cara bertingkah laku manusia dalam kehidupannya yang menjadi suatu identitas [1]. Sri Sultan Hamengku Buwono X [2] mengatakan bahwa permasalahan budaya daerah saat ini, pengaruh arus budaya luar, kearifan budaya lokal yang berasal dari budaya daerah yang dapat dijadikan "modal dasar baru" bagi persatuan dan kesatuan bangsa atas dasar solidaritas sosial budaya rakyat yang saling menghargai sesama warga Indonesia, keperdulian pemerintah terhadap budaya daerah, serta kebijaksanaan kraton-kraton di daerah dan pemangku-pemangku adat yang demokratis perlu dilestarikan dan dikembangkan sebagai landasan budaya daerah. Kearifan lokal-tradisional yang terdapat pada budaya daerah merupakan sumber identitas budaya bangsa. Nilai-nilai budaya yang ada harus dilihat sebagai bagian dari masa depan republik Indonesia dan harus dikembangkan secara kreatif. Pengenalan gamelan sebagai identotas budaya bangsa Indonesia dilakukan melalui ekstrakurikuler karawitan. Namun kita sebagai fisikawan dan guru fisika dapat mengajarkan konsep fisika menggunakan gamelan. Sehingga selain mengenalkan gamelan juga konsep fisika bisa kita dapatkan. 
Fenomena fisika ada di dalam gamelan. Selama ini proses pembelajaran fisika hanya berkutat pada fenomena fisika dan tidak membahas budaya. Melalui berbagai kajian dan eksperimen maka gamelan dapat dipelajari untuk digunakan sebagi media pembelajaran fisika. Siter, saron, kenong, kendang, dan gender merupakan beberapa alat musik yang ada dalam gamelan. Didalamnya terdapat potensi untuk didalami sehingga bisa digunakan dalam prose pembelajaran.

Tujuan telaah ini adalah:

a) Menemukan konsep dan cara untuk menggunakan siter sebagai media pembelajaran fisika

b) Menemukan konsep dan cara untuk menggunakan kendang sebagai media pembelajaran fisika

c) Menemukan konsep dan cara untuk menggunakan saron dan kenong sebagai media pembelajaran fisika

d) Menemukan konsep dan cara untuk menggunakan gender sebagai media pembelajaran fisika

\section{Kajian Pustaka}

Studi mengenai gamelan untuk dimanfaatkans ebagai media pembelajarn fisika sangat jarang dilakukan oleh peneliti. Proses pemikiran fenomena fisika dalam gamelan sangat menarik. Fisika ada di dalam gamelan dan menunggu untuk diungkap lebih lanjut.

\section{Media pembelajaran fisika}

Media adalah perantara untuk mengantarkan informasi dari pemberi informasi ke penerima. Media pembelajaran adalaha perantara yang dapat memberikan informasi dari guru berupa konsep fisika kepada siswa. Menurut Association of Education and Communication Technology [3] di Amerika media adalah segala bentuk dan saluran yang digunakan orang untuk menyampaikan pesan/informasi. Menurut Gagne media adalah berbagai jenis komponen dalam lingkungan siswa yang dapat merangsangnya untuk belajar. Briggs mengatakan media adalah segala alat fisik yang dapat penyajikan pesan serta merangsang siswa untuk belajar. National Education Association [4] : media adalah bentuk-bentuk komunikasi baik tercetak maupun audiovisual serta peralatanya. Bahasa latin "medium" yang secara harfiah berarti "perantara" yaitu perantara sumber pesan (a source) dengan penerima pesan (a receiver). Media pembelajaran fisika adalah alat atau perantara untuk mengajarkan konsep fisika dari sumber ke penerima (peserta didik).

Dengan media pembelajaran siswa dapat berinteraksi langsung dengan fenomena fisika yang dipelajari. Proses pembelajaran menjadi lebih efektif karena adanya pengalaman nyata siswa melalui media yang digunakan. Media adalah jembatan untuk mengajarkan konsep dari guru ke siswa tersebut. Objek yang terlalu kecil, terlalu besar, terlalu rumit, dan jarang ditemui dapat dijelaskan dengan mudah dengan menggunakan media pembelajaran.

Menurut Ridwan [5] pembelajaran berbasis inkuiri adalah pembelajaran yang melibatkan siswa dalam merumuskan pertanyaan yang mengarahkan untuk melakukan investigasi dalam upaya membangun pengetahuan dan makna baru. Dalam hal ini siswa berperan aktif dalam mencari dan menbangun pengetahuanya sendiri. Penelitian yang dilakukan oleh Eko [6] menggunakan gamelan sebagai media pembelajaran sains untuk mengajarkan konsep getaran gelombang dan bunyi. LKS yang dibuat telah mampu menunjukkan beberapa model pemanfaatan alat musik gamelan dalam proses pembelajaran fisika.

\section{Metode Penelitian}

Metode penelitian yang digunakan adalah peneltian kualitatif. Penelitian kualitatif digunakan untuk melakukan studi pustaka untuk mendapatkan informasi konsep apa dan bagaimana cara untuk memanfaatkan alat musik siter, kendang, kenong, saron, dan gender dalam pembelajaran fisika. Hasilnya diharapkan dapat dijadikan rujukan pemanfaatan gamelan dalam proses pembelajarn fisika.

\section{Hasil Penelitian dan Pembahasan}

Pembelajaran IPA Fisika di SMP di kelas VIII semester 2 mengehendaki siswa menguasai konsep getaran gelombang dan bunyi. Hal ini tertuang dalam KI dan KD dari siswa SMP kelas VIII semester 2. Gamelan yang menghasilkan bunyi dapat dikaitkan untuk melaksanakan proses pembelajaran fisika pada kelas ini. Materi yang harus dikuasai antara lain konsep getaran, konsep tinggi rendah dan kuat lemah bunyi, konsep hubungan panjang tali dengan frekuensi bunyi, dna konsep awal resnonansi bunyi. Hasil dari telaah dan kajian alat musik siter, kendang, saron dan kenong dalam pembelajaran fisika adalah sebagai berikut:

\section{Pemanfaatan siter sebagai media pembelajaran materi getaran}

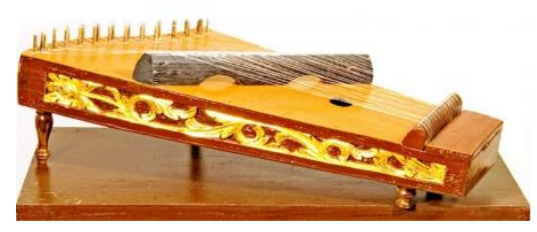

Gambar 1. Siter [7]

Siter adalah alat musik petik pada instrument gamelan. Alat musik ini mempunyai banyak dawai yang disusun dalam sebuah kotak. Setiap dawai mewakili satu nada. Siter dapat digunakan dalam pembelajaran fisika sebagai media pembelajaran fisika. Konsep yang dapat dibangun menggunakan sister sebagai media pembelajaran fisika antara lain:

\section{Getaran}

Prosedur eksperimen yang dapat dilakukan untuk memanfaatkan siter sebagai media pembelajaran 
fisika telah dituangkan dalam penelitian Eko [6] yaitu: a). siswa diminta memetik siter hingga bergetar, b). siswa diminta melihat getaran pada siter dan menjawab pertanyaan "apakah dawai bergerak ke kiri dan ke kanan (bolak-balik)?”, c). siswa diminta menjawab pertanyaan "apakah ada titik dimana dawai sama dengan posisi awalnya (titik setimbang)?”, d). siswa diminta mengisi kalimat rumpang "getaran adalah gerak ....... melewati ........."

Melalui keempat prosedur dasar tersebut sier dapat digunakan sebagai media untuk mengajarkan konsep getaran. Alat musik lain yang dapat digunakan dengan cara yang sama adalah gitar, sasando, kencrung, kecapi, dan alat musik petik lainya.

\section{Tinggi rendah bunyi}

Siter dapat dipetik pada nada rendah dna nada tinggi untuk mengajarkan konsep tinggi-rendah bunyi. Cukup dengan memetik siter pada dawai yang panjang akan diperoleh nada rendah (frekuensi rendah). Memetik siter pada dawai pendek akan diperoleh nada tinggi (frekuensi tinggi).

\section{Hubungan antara panjang tali dan frekuensi bunyi}

Siter dapat digunakan dengan baik untuk menjelaskan hubungan antara panjang tali dan frekuensi bunyi. Dapat dilihat dengan jelas bahwa semakin pendek panjang tali maka akan semakin tinggi nada pada dawai siter. Sebaliknya semakin panjang dawai siter semakin rendah nada bunyi yang dihasilkan. Persamaan yang dipakai adalah:

$$
f=\frac{1}{2 l} \sqrt{\frac{T}{\mu}}
$$

Dimana $f$ adalah frekuensi bunyi, $T$ adalah tegangan tali, 1 adalah panjang tali, dan $\mu$ adalah massa per satuan panjang tali. Dengan asumsi tegangan tali dan massa pers atuan panjang tali tetap.maka hubungan panjag dawi dan frekensi dapat diamati.

Tabel yang dapat digunakan untuk melihat hubungan ini dapat dilihat pada tabel 1 .

Table 1. Pengamatan panjang tali vs frekuensi bunyi.

\begin{tabular}{ccc}
\hline No & Panjang dawai $(\boldsymbol{m})$ & Frekuensi $(\mathrm{Hz})$ \\
\hline 1 & & \\
2 & & \\
3 & & \\
$\ldots$ & \\
\hline
\end{tabular}

Pengukuran panjang dawai dapat menggunakan penggaris biasa dan pengukuran frekuensi dapat menggunakan aplikasi android "Sound Analyzer Free" yang dapat didownload melalui google playstore. Tampilan contoh hasil analisis aplikasi dapat dilihat pada gambar. Cukup tekan tombol berhenti maka grafik akan berhenti dan menampilkan frekuensi dari dawai yang dipetik. Puncak tertinggi dari grafik yang ada adalah frekuensi bunyi yang dimaksud sedangkan tinggi puncaknya merupakan intensitas bunyinya.

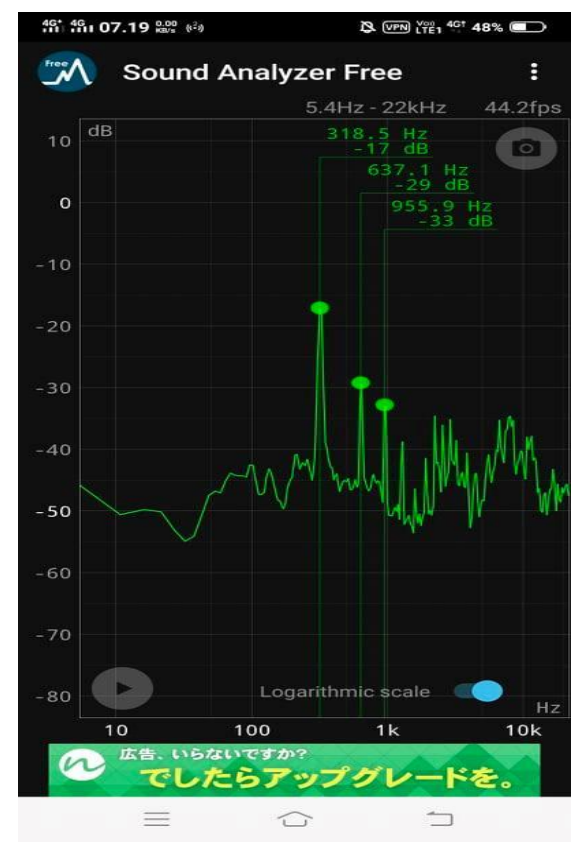

Gambar 2. Tampilan sound analyser free

\section{Pemanfaatan kendang sebagai media pembelajaran materi bunyi}

Kendang adalah alat musik yang terdiri dari sebuah kolom dengan membrane di kedua ujungnya. Kolom biasanya dibuat dari kayu dan membrane biasanya dibuat dari kulit binatang ternak seperti sapi atau kambing.

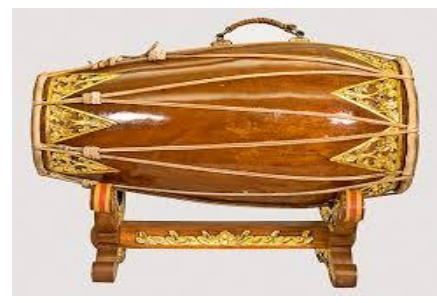

Gambar 3. Kendang

Konsep bunyi berasal dari getaran dapat disampaikan dengan eksperimen sebagia berikut: a). berdirikan kendang sehingga membrane berada di bagian atas, b). taburi membrane tersebut menggunakan beras, c). pukul bagian membrane dengan hati-hati hingga mendengar bunyi, d). amati beras dan jawab pertanyaan "apakah beras bergerak naik dan turun”, e). jawab pertanyaan "apakah beras mengalami getaran dan apakah membran menghasilkan bunyi?, f). buatlah kesimpulan dari percobaan ini.

Dengan menggunakan prosedur diatas maka akan terlihat bahwa jika ada bunyi maka beras akan naik dan 
turun yang mengidikasikan adanya getaran. Konsep bunyi berasal dari getara dapat dibuktikan menggunakan kendang. Alat musik lain yang dapat digunakan dengan cara serupa adalah drum, rebana, bedug dll.

\section{Pemanfaatan saron dan kenong sebagai media pembelajaran materi bunyi}
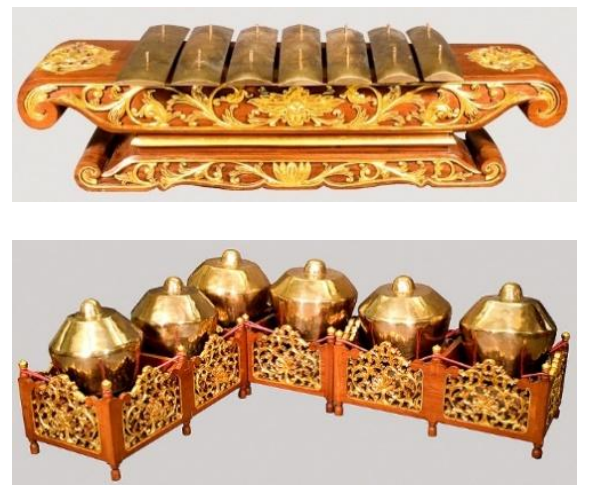

Gambar 4. Saron (atas) dan kenong (bawah) [9]

Saron dan kenong merupakan dua alat musik yang berbeda. Gambar saron dan kenong dapat dilihat pada gambar. Kedua alat musik ini dapat digunakan untuk menjelaskan kuat lemah bunyi dan tinggi rendah bunyi. Saron dan kenong dapat dipukul pada nada rendah dan nada tinggi untuk mendemonstrasikan frekuensi tinggi dan frekuensi rendah sebagai dasar konsep tinggi-rendah bunyi. Selain itu dengan mengontrol ketinggian pemukul saron dan kenong maka dapat didengar bunyi dengan intensitas tinggi dan intensitas rendah. Pemukul yang dijatuhkan dari ketinggian $5 \mathrm{~cm}$ dengan $10 \mathrm{~cm}$ akan menghasilkan intensitas bunyi yang berbeda. Intensitas bunyi tinggi berasal dari amplitude bunyi yang besar dan sebaliknya intensitas bunyi yang rendah berasal dari amplitude yang kecil. Keras-lemah bunyi bergantung pad aamplitudonya. Kuat-lemah dan tinggi rendah bunyi ini dapat diamati dengan menggunakan aplikasi android "Sound Analyzer Free" yang dapat didownload melalui google playstore. Fekuensi dan intensitas bunyi dapat diketahui dari software tersebut.

\section{Pemanfaatan gender sebagai media pembelajaran getaran}

Gender adalah salah satu alat musik yang berupa kepingan logam segiempat yang digantung pada 4 tiang kecil dan disusun sedemikian rupa sehingga bilah logam segiempat tersebut seperti melayang (gambar 5). Yang menarik dari alat musik ini adalah adanya kolom udara di bawah bilah logam ini. Kedalaman dari kolom udara yang biasanya terbuat dari pipa ini berbeda beda. Dapat dilihat bahwa semakin tinggi nadanya (frekuensi semakin besar) semakin dangkal kedalaman kolomnya. Semakin rendah nadanya semakin dalam kedalamanya.

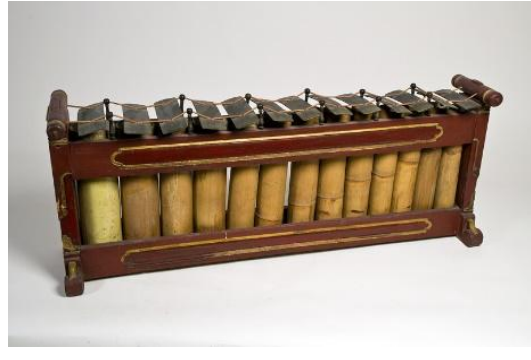

Gambar 5. Gender [10]

Hal ini dapat digunakan untuk menjelaskan pipa organa tertutup dimana satu sisi ditutup dan satu sisi lainya dibuka. Persamaan yang digunakan adalah:

$$
f=\frac{v}{4 l}
$$

$f$ adalah frekuensi bunyi. $l$ adalah kedalaman kolom, dan $v$ adalah kecepatan bunyi di udara.

Siswa dapat mengisi table sebagai awal dari pembahasan materi resonansi pada pipa organa tertutup ini. Sma seperti sebelumnya frekuensi dapat dianalisis menggunakan aplikasi android "Sound Analyzer Free" yang dapat didownload melalui google playstore dan kedalaman dapat diukur menggunakan penggaris.

Tabel 2. Percobaan hubungan frekuensi dan kedalaman pada gender.

\begin{tabular}{ccc}
\hline No & Frekuensi $(\mathbf{H z})$ & Kedalaman kolom $(\mathbf{m})$ \\
\hline Ji & & \\
Ro & \\
Lu & \\
$\ldots$ & & \\
\hline
\end{tabular}

\section{Kesimpulan}

Kesimpulan dari kajian ini adalah:

a) Siter dapat digunakan untuk menjelaskan konsep getaran, tinggi rendah bunyi dan hubungan panjang tali dengan frekuensi bunyi. Frekuensi bunyi diukur menggunakan aplikasi sound analyser free.

b) Kendang dapat digunakan untuk menjelaskan konsep bunyi berasal dari getaran melalui eksperimen dengan menaburkan beras diatasnya.

c) Saron dan kenong dapt digunakan untuk menjelaskan tinggi-rendah dan kuat lemah bunyi dengan memukul pada nada berbeda untuk mengajarkan tinggi rendah bunyi dan mengatur tinggi rendahnya pemukul untuk mengajarkan kuat lemah bunyi.

d) Gender dapat digunakan untuk menjelaskan resonansi pipa organa tertutup dengan mengukur kedalaman dari kolom dibawah bilah logam dan mencatat frekuensinya. 
Saran-saran yang untuk pengembangan lebih lanjut adalah

a) Perlu dibuat sebuah modul/Lks/buku untuk mewadahi proses pembelajaran menggunakan gamelan ini

b) Resonansi pada kolom di alat musik gender lebih diperlukan analisis lebih mendalam agar terbukti kebenaranya dan ada factor koreksi jika diperlukan

\section{Kepustakaan}

[1] Y.T.C Pramudi et all, 2010, Desain Virtual Gamelan Jawa Sebagai Media Pembelajaran, Seminar Nasional Aplikasi Teknologi Informasi, Yogyakarta

[2] Sultan Hamengku Buwono X, 2007, Merajut Kembali Keindonesiaan Kita, Gramedia Pustaka Utama, Jakarta

[3] AECT (Association for Educational Communication and Technology). Evaluating Media Programs District and School, Washington, D.C : The Association, 1976.

[4] National Education Association, 2016, 2016-2017 NEA Resolusitons, USA

[5] Ridwan AS, 2013, Pembelajaran Saintifik untuk Implementasi Kurikulum 2013, Bumi Aksara, Jakarta

[6] Eko Nursulistiyo, (2012), Pengembangan Modul pembelajaran sains dengan media pembelajaran gamelan untuk meningkatkan pemahaman dan aplikasi konsep siswa SMP, Tesis, Universitas Negeri Yogyakarta

[7] Tim Kamera budaya, 2016, Alat Musik tradisional Siter, https://www.kamerabudaya.com/2016/10/alat-musik-tradisionalsiter.html, diakses 24 Juni 2019

[8] Alfirochmah, apa yang anda ketahui mengenai alat musik kenong, (https://www.dictio.id/t/apa-yang-anda-ketahui-tentangalat-musik-tradisional-kenong/52630), diakses 24 Juni 2019

[9] European Union, Gender barung (gamelan pelog), https://www.europeana.eu/portal/en/record/09102/_spk_obj_2575 02.html, Europe diakses 24 Juni 2019 